\title{
Evolving Statutory Derivative Action Principles in South Africa: The Good Faith Criterion and Other Legal Grounds
}

\author{
Brighton M Mupangavanhu* \\ University of the Western Cape, Cape Town, South Africa \\ bmupangavanhu@uwc.ac.za
}

\begin{abstract}
The recent Supreme Court of Appeal (SCA) judgment in Lazarus Mbethe $v$ United Manganese of Kalahari raises jurisprudential questions regarding statutory derivative actions in South Africa. For example, the SCA did not agree with the court a quo's ruling that the discretion to be exercised by the court is limited by provisions of section 165(5). The SCA also questioned whether it is necessary for South African courts to follow the good faith criterion in the Australian case of Swansson $v$ Pratt as adopted into South African law through Mouritzen $v$ Greystones Enterprises (Pty) $L t d \&$ Another. This article contributes to these questions, and proposes possible criteria for other requirements in section 165(5)(b) of the Companies Act 71 of 2008. These other requirements are that the statutory derivative action proceedings must involve "a trial of a serious question of material consequence to a company" and that proceedings be "in the best interests of the company".
\end{abstract}

\section{Keywords}

Statutory derivative action proceedings, requirements, Companies Act 71 of 2008, court's overriding discretion, proper plaintiff rule, internal management principle

\section{INTRODUCTION}

The question regarding who has a right to bring action on behalf of a company when it has been wronged is an important part of the corporate form. The concept of the separate legal personality of a company ${ }^{1}$ implies that a

* Senior lecturer, Mercantile and Labour Law Department, Faculty of Law, University of the Western Cape. The author acknowledges St John's College, Cambridge University, UK, for the very generous funding received through the Beaufort (Colenso) Visiting Scholar Fellowship, which enabled the author to conduct research leading to publications, including this article, during the Lent and Easter terms, 2020.

1 See the English case of Salomon $v$ Salomon \& Co Ltd [1897] AC 22 (HL). Principles of separate legal personality of a company were adopted into South African law through Dadoo Ltd $v$ 
corporation, as an abstraction, can only operate through human agency. ${ }^{2}$ In terms of South Africa's Companies Act 71 of 2008 (the Act), the relevant company organ authorized to exercise a company's powers, and to act on its behalf to enable it to achieve its corporate objectives, is the board of directors. ${ }^{3}$ Generally, if an actionable wrong has been done to a company, that is, where a company has been wronged or has suffered harm, it is for the company itself to take remedial action, just like any other legal person. By "company", as constructed from section 66(1) of the Act, is meant the legally recognized representative organ of the company, the board of directors. For example, it is the company that has a right to bring action against a director for breach of a director's duty since the duty is owed to the company. This is for the reason that fiduciary duties and the duty of care are owed to the company, and to the company alone. This is unexceptionable and flows from the fact that the directors are agents of the company and stewards of its affairs and not stewards of the affairs of shareholders. ${ }^{4}$ This is the essence of the "proper plaintiff rule"..$^{5}$ If the alleged wrong done to the company is a matter that is appropriate for the company to settle itself (the internal management principle) ${ }^{6}$ or, in the case of an irregularity, to ratify or condone by its own internal procedure (the irregularity principle), then no individual member/ shareholder may bring action. ${ }^{7}$ The decision therefore generally rests with the board of directors.

It often happens in practice that the board is disinclined to initiate proceedings against one of its own members. ${ }^{8}$ Such a situation threatens the company's interests.

contd

Krugersdorp Municipal Council 1920 AD 530. Now the Act confirms this position in sec 19 (1)(a)-(b).

2 In Lennard's Carrying Co Ltd v Asiatic Petroleum Co Ltd [1915] AC 705, Lord Richard Burdon Haldane made a telling remark in this regard. He said (at 713): "A corporation is an abstraction. It has no mind of its own any more than it has a body of its own; its active and directing will must consequently be sought in the person of somebody who for some purposes may be called an agent, but who is really the directing mind and will of the corporation, the very ego and centre of the personality of the corporation".

3 See sec 66(1) of the Act. The board in this regard has authority to decide whether or not to take action on behalf of the company, subject to the right of derivative action available to stakeholders.

4 See Sharp and Others $v$ Blank and Others [2015] EWHC 3220 (Ch). See also, Percival $v$ Wright [1902] 2 Ch 421.

5 (1843) 2 Hare 461. In this case, two shareholders, Foss and Turton, initiated proceedings as a class action in the interests of similarly affected members of the corporation. The court held that the action did not lie at the suit of the shareholders.

6 See Burland and Earle [1902] AC 83 at 93.

7 S Worthington Sealy $\mathcal{G}$ Worthington's Text, Cases $\mathcal{G}$ Materials in Company Law (11th ed, 2016, Oxford University Press) at 669.

8 J Cassidy Concise Corporations Law (5th ed, 2006, The Federation Press) at 302. 
At common law, a shareholder who believes that legal action should be taken in order to protect the threatened interests of the company ${ }^{9}$ can approach a court for an order to effectively compel the company to do so. The law makes it possible that in one way or another, some means must be found for the company to protect its legitimate interests against possible harm. ${ }^{10}$ This in essence is the common law derivative action. The action is "derivative" since the right of action in law derives from the power of the company to take action to enforce its right and thus to protect its threatened interests. ${ }^{11}$ The common law derivative action has its origins in the so-called exceptions set out in Foss $v$ Harbottle. ${ }^{12}$ These are exceptions to the general rule that the company is the proper plaintiff in bringing action to redress a wrong done to it. It is vital to note that even at common law a member (shareholder) seeking to advance derivative action against the company bore the onus to prove two critical factors. ${ }^{13}$ The first was the existence of the right of the company relied upon. ${ }^{14}$ The second factor was the breach of the duty owed to the member by the company. ${ }^{15}$ Thus, the right of the shareholder or member to proceed with the action was not unqualified at common law. ${ }^{16}$ Whether or not to grant the remedy to the applicant was subject to a court's discretion Even in terms of the now-abolished Companies Act 61 of 1973 (the Companies Act 1973), a derivative action applicant bore an onus of satisfying the court of the existence of a prima facie case of wrongdoing to justify the appointment of a provisional curator ad litem. ${ }^{17}$ Such a curator had to be appointed to investigate whether the alleged wrong had been committed, and whether it was desirable to involve the company in legal proceedings. ${ }^{18} \mathrm{In}$

9 In circumstances in which the company board of directors has not taken appropriate action to protect the company's interests.

10 See a similar view expressed by an English court in Wallersteiner v Moir (No 2) [1975] All ER 849 (CA), para 857.

11 As remarked in the American case of Schiowitz $v$ IOS Ltd (1971) 23 DLR (3d) 102. See also a similar view expressed in Tshivhase "The Mouritzen case and the new era of derivative actions" (2012) 12 Without Prejudice 26.

12 These exceptions include: ultra vires or illegal acts, as confirmed in Atherton v Plane Creek Central Mill Co Ltd (1914) St R Qd 73 at 93; the absence of any necessary authorizations by a special majority of the company in general meeting or class of shareholders - see Baillie $v$ Oriental Telephone Co [1915] 1 Ch 503; fraud on the minority - see Daniels v Daniels [1978] Ch 406; and breaches of members' personal rights - as confirmed in Residues Treatment and Trading Company Ltd $v$ Southern Resources Ltd (1988) 6 ACLC 1160.

13 I speak in the past tense since the common law right has now been replaced by the statutory provision in sec 165 .

14 See Lazarus Mbethe $v$ United Manganese of Kalahari (Pty) Ltd (503/2016) [2017] ZASCA 67 (30 May 2017), para 14.

15 Ibid.

16 Ibid.

17 This was in terms of sec 266 of the old Companies Act 1973.

18 Mbethe 2017, above at note 14, para 15. 
all the derivative actions before the current Act, the court exercised an overriding discretion whether or not to grant the remedy, and the applicant bore an onus of proving the desirability for a court to grant such a remedy. There are very important practical reasons and policy rationales as to why the law imposes an onus on an applicant to satisfy the court of the need to grant leave to bring a derivative action on behalf of the company, and why the court has to exercise discretion. For the purposes of this article, these two points are important to note, and will be dealt with in detail later in this article.

The current Act introduced a new statutory derivative action regime in section 165. Parts of this provision, especially section 165(2), have received the attention of courts and commentators. There appear to be disagreements among lawyers, including judges, on some other aspects of section 165. For example, the Supreme Court of Appeal (the SCA) in Lazarus Mbethe $v$ United Manganese of Kalahari (Pty) Ltd 19 (Mbethe 2017) does not agree with the High Court's view ${ }^{20}$ that the discretion to be exercised by the court is limited by the provisions of section 165(5). Another point of divergence between the high courts and the SCA pertains to the question of whether South African courts now follow the good faith criterion in the Australian case of Swansson $v$ RA Pratt Properties Pty Ltd ${ }^{21}$ (Swansson), which was initially imported into South African law by another High Court in Mouritzen $v$ Greystones Enterprises (Pty) Ltd \& Another (Mouritzen). ${ }^{22}$

This article seeks to establish clarity on a few interrelated issues. Firstly, the article seeks to confirm the place of a South African court's exercise of discretion in granting leave to undertake derivative action and the rationale thereof. $^{23}$ The article further examines whether it is necessary for South African courts to follow the Swansson good faith criterion as suggested in Mouritzen, and as seemingly now outlawed by the SCA. In that same vein, it is considered vital to sketch the proper interpretation of provisions of the current Act as seen from the bowels of the Act and in terms of the constitutional matrix of interpretation of statutes. The latest Mbethe 2017 applies the requirement that proceedings should involve "a trial of a serious question of material consequence to a company" under section 165(5)(b), without providing meaning or espousing a relevant criterion. This article intends to provide a commentary on these developments.

19 Id, para 18.

20 See the High Court's ruling in Mbethe $v$ United Manganese of Kalahari (Pty) Ltd [2016] ZAGP JHC 8 (11 February 2016); 2016 (5) SA 414 (GJ).

21 [2002] NSWSC 583 (3 July 2002).

222012 (5) SA 74 (KZD). See para 51. Also see Mbethe 2016, above at note 20, para 170, which confirms the Swansson approach as adopted in Mouritzen.

23 The SCA recently found it necessary to confirm this matter in Mbethe 2017, above at note 14, para 18. 


\section{BRIEF BACKGROUND AND POLICY RATIONALES FOR SECTION 165}

The predecessor to section 165 of the present Act is section 266 of the Companies Act 1973. Section 266 proved ineffectual for various reasons. One of the greatest obstacles to shareholder activism in the context of the statutory derivative action under section 266 was the issue of inhibiting costs of litigation, which costs were borne by the minority shareholder litigant. ${ }^{24}$ For example, a shareholder who instituted proceedings is not the one who benefited in the event of a successful award of damages by a court. ${ }^{25}$ The benefit would accrue to the company and not to the litigant. ${ }^{26}$ Another problem associated with section 266 was its restrictive scope. In this regard, only a shareholder could institute proceedings to protect the threatened legal interests of a company. ${ }^{27} \mathrm{~A}$ third challenge was that in order for section 266 to be invoked, a company must have suffered damages or must have been deprived of any benefit as a result of "any wrong, breach of trust or breach of faith" committed by a director or officer, and no one else. ${ }^{28}$ The implication of this challenge was that it restricted the breadth and reach of the statutory derivative action and thus contributed to it being rendered less effective.

If the promise and hope of law reform in the arena of derivative action held by the Van Wyk de Vries Commission in $1970^{29}$ was disappointed by the shortfalls found in section 266, the objectives of law reform in the Department of Trade and Industry (DTI) policy document ${ }^{30}$ that resulted in the present Act sought to address the challenges associated with section 266 . The Companies Bill 2007 broadly states the rationale of section 165 as one of “... streamlining of the right to commence or pursue legal action in the name of the company, which replaces any common law derivative action". ${ }^{31}$ Thus, some of the broad policy rationales for the reform of statutory derivative action under section 266 include promotion of shareholder activism and protection of minority shareholders' rights. This includes provision of a remedy that empowers minority shareholders to institute proceedings aimed at protecting company interests where the company board has failed to do so. ${ }^{32}$

24 L Coetzee "A comparative analysis of the derivative litigation proceedings under the Companies Act 61 of 1973 and the Companies Act 71 of 2008” (2010) Acta Juridica 296.

25 Ibid.

26 Ibid.

27 C Stein New Companies Act Unlocked (2011, Siber Ink) at 370-71.

28 Ibid.

29 Van Wyk de Vries Commission of Inquiry into the Companies Act, Main Report R P 45/1970.

30 See the policy document drafted by the DTI entitled "Company law for the 21st century" GG 26493 of 23 June 2004.

31 Explanatory Memorandum to the Companies Bill, 2007 at 14.

32 The proceedings on behalf of the company may be aimed for example at recovering damages or property for the company in circumstances where the directors have improperly refused to do so. See MF Cassim "The statutory derivative action under the Companies Act of 2008: The role of good faith” (2013) 130 South African Law Journal 496 at 500. 
The twin goals of promotion of shareholder activism and minority shareholder protection form part of the aims of the DTI policy document. ${ }^{33}$

In light of the above, it would seem that the second policy rationale is to provide a mechanism to prevent abuse of power by those in control of company affairs by putting in place checks and balances in corporate governance. This potentially deters managerial misconduct and inaction that threaten company interests. Such an objective gives effect to some purposes of the Act, especially the need to encourage the efficient and responsible management of companies. ${ }^{34}$

A third policy rationale is to extend locus standi for purposes of applying for remedies for selected categories of persons affected by the inaction of directors and the consequent threat to the interests of the company. ${ }^{35}$ This is a direct response to one of the limitations of section 266 of the Companies Act 1973. Only a shareholder could institute proceedings as aforementioned. In terms of the new Act, standing has been extended to shareholders, directors or prescribed officers of the company or those of a related company, registered trade unions, and anyone who, in the discretion of the court should be permitted to undertake action to protect company interests. ${ }^{36}$

A fourth rationale seeks generally to extend the scope and reach of the statutory derivative action in order to enhance its effectiveness. This broad rationale includes the stretching or application of the derivative action beyond controllers of the company to include wrongs committed by outsiders against whom the controllers decline to act. Controllers such as directors could be reluctant to act against these outsiders for reason of their close ties with such persons and their desire to protect them from litigation. ${ }^{37}$

\section{INTERPRETATION OF SECTION 165(5): THE LEGAL FRAMEWORK}

The task of interpreting provisions of the Act has assumed great importance when one considers that new principles developed by the courts have evolved from the process of decoding the meaning of the provisions of the Act. For example, the court in Mouritzen developed a good faith criterion which was born out of the interpretation of section 165(5)(b)(i), compared with an Australian approach in Swansson. ${ }^{38}$ In Mbethe 2017, the central dispute was

33 See Memorandum on the objects of the Companies Bill, 2008, Companies Bill 61D of 2008 para 1.2.4. Also see Cassim "The statutory derivative action”, above at note 32 at 504 .

34 See the Act, sec 7(j).

35 The extension of locus standi through sec 157 of the Act is analogous to the manner in which sec 38 of the Constitution of the Republic of South Africa, 1996 has generally extended legal standing to promote enjoyment of rights as provided for under the Bill of Rights.

36 See the Act, sec 165(2), which should be read with sec 157 which provides what is appropriately titled "Extended standing to apply for remedies".

37 See Cassim "The statutory derivative action", above at note 32 at 500.

38 See the Introduction to this article. Also see Mouritzen, above at note 22, para 58, and further see Swansson, above at note 21, paras 36-37. 
around the parties' divergent views on the correctness of the court a quo's conclusion as to what had to be proved to establish the requirement of good faith. ${ }^{39}$ That too was clearly a dispute based on the proper interpretation of section 165(5).

Mupangavanhu, in his thesis, remarks that interpretation of provisions of the Act "is to take place visceribus actus (from the bowels of the Act) or as part of the more encompassing legislative instrument in which it has been included". ${ }^{40}$ This is a construction made from the reading of section 5(1) of the Act. That section provides that the Act must be interpreted and applied in a manner that gives effect to its purposes as set out in section 7 . This is a purposive or contextual approach to interpretation of statutes. Policy rationales for derivative actions have already been outlined above. ${ }^{41}$ It must be added here that the context is so elastic that it demands a holistic approach to interpretation of statutes. Such an approach requires that regard must be had to the history of the provision, common law prior to enactment of the Act, defects in law not provided for by common law, new remedies provided for by the legislation ${ }^{42}$ and the national context relevant to interpretation of statute. ${ }^{43}$

The national context referred to above in South Africa implies a need for teleological interpretation of derivative actions and any other provision of the Act. Teleological interpretation means that the Constitution of the Republic of South Africa (the Constitution), ${ }^{44}$ which is the supreme law of the land, ${ }^{45}$ provides a normative value system (or the context) against which all law and all actions are evaluated and measured. ${ }^{46}$ The Constitution provides a statutory interpretation clause, viz section 39(2). It has been held in South African case law that section 39(2) provides "the starting point in interpreting any legislation". ${ }^{47}$ Section 39(2) mandates courts and every tribunal or

39 Mbethe 2017, above at note 14, para 9.

40 BM Mupangavanhu Directors' Standards of Care, Skill, Diligence and the Business Judgment Rule in View of the Companies Act 71 of 2008: Future Implications for Corporate Governance (2016, published PhD thesis, University of Cape Town) at 194. The term visceribus actus was commonly employed by de Ville, see de Ville Constitutional and Statutory Interpretation (2000, Juta) at 142.

41 This part needs to be understood in conjunction with purposes of the Act set out in sec 7 .

42 See similar principles laid down in Jaga $v$ Donges NO and Another; Bhana Donges NO and Another 1950 (4) SA 653 (A) 662, referred to in Mupangavanhu Directors' Standards of Care, above at note 40 .

43 These are the "intra-textual and extra-textual factors", as they are called by Botha, see Botha Statutory Interpretation: An Introduction for Students (5th ed, 2013, Juta) at 98.

44 Constitution of the Republic of South Africa, 1996.

45 Id, sec 2 provides: "This Constitution is the supreme law of the Republic, law or conduct inconsistent with it is invalid, and the obligations imposed by it must be fulfilled."

46 Botha Statutory Interpretation, above at note 43 at 99.

47 See the remarks of Ngcobo J in Bato Star Fishing (Pty) Ltd $v$ Minister of Environmental Affairs and Tourism 2004 (4) SA 490 (CC), para 72. 
adjudicating forum to promote the "spirit, purport and objects of the Bill of Rights" when interpreting and applying law to a given situation. ${ }^{48}$ In language that is reminiscent of section 39(2), the Act provides that courts and other forums "must promote the spirit, purpose and objects of the Act" when determining a matter brought before it in terms of the Act or when making any order. ${ }^{49}$ Section 158 will prove to be very important in the interpretation of the Act for at least two reasons, and especially where remedies are sought by parties. In addition to section 7 (a) as already indicated, section 158 promotes compliance with the overarching constitutional values under the Bill of Rights in the interpretation and application of company law. Apart from mandating courts to "promote the spirit, purpose and objects of this Act" when determining a matter brought before them, ${ }^{50}$ section 158 also requires courts to develop the common law as necessary to improve realization and enjoyment of rights. ${ }^{51}$ The rights referred to are especially rights established by the Act. It is beyond the scope of this article to explore the full implication of section 158, which is the subject of a future article.

Another important provision in interpretation of derivative action provisions is section 5(2) of the Act. ${ }^{52}$ This provision allows courts to expand the context of the law during interpretation - beyond the national realm, objectives of law reform, purposes of the Act and history of the law - to include international experiences relevant to the development of jurisprudence in South Africa. ${ }^{53}$ Harmonization of South African company law with best practice jurisdictions internationally formed part of law reform objectives. ${ }^{54}$ It is little wonder that our courts have borrowed principles evolving from Australian law, for example, as was done by the court in Mouritzen when it followed the good faith criterion in the Australian case of Swansson. ${ }^{55}$

As previously intimated, section 157, which is aptly titled "Extended standing to apply for remedies", is relevant to interpretation of statutory derivative actions. Persons who may approach the court seeking remedies in terms of derivative actions extend beyond those who can be said to be directly contemplated in a provision of the Act. Included within the ambit of section 157 is a person acting in a representative capacity, that is, a person acting on behalf

48 Of relevance in this regard in the context of the Act is a purpose to "promote compliance with the Bill of Rights as provided for in the Constitution, in the application of company law". This is listed as the first purpose of the Act in sec 7(a).

49 See the Act, sec 158(b).

50 See id, sec 158(b)(i).

51 See id, sec 158(a).

52 It provides that "to the extent appropriate, a court interpreting or applying this Act may consider foreign company law".

53 Mupangavanhu Directors' standards of care, above at note 40 at 196.

54 See DTI Company Law for the 21st Century, above at note 30, para 3.5.

55 See the Introduction to this article. 
of a person directly affected. ${ }^{56}$ Class actions are also permitted in terms of the Act, and thus a trade union representing employees in a workplace may approach a court seeking remedies on behalf of its members. ${ }^{57}$ Interestingly, a person may even bring action in public interest, especially where the business of a company touches on public interest. ${ }^{58}$

\section{A COURT'S GRANTING OF LEAVE TO BRING ACTION ON BEHALF OF THE COMPANY: THE LEGAL GROUNDS UNDER SECTION 165 (5)(B)}

This article focuses on part of the legal grounds listed in section 165(5)(b) upon which a court may grant leave to bring or continue proceedings on behalf of the company. While there seem not to be too many problems with the grounds listed in sections 165(5)(a), courts and lawyers, however, appear to disagree on elements of the grounds listed in section 165(5)(b). As already highlighted above, courts have disagreed on whether to follow the Australian approach's good faith criterion. Some South African courts appear also to disagree on whether the discretion to be exercised by the courts in terms of section 165(5) remains an overriding discretion, as was the case prior to the Companies Act 2008, or whether the Act now limits that discretion. ${ }^{59}$ Since the elements of the grounds in section 165(5)(b) are conjunctive, it follows that they can only be better understood in tandem rather than in isolation. As noted in Mbethe 2017, for example, in considering whether the "proceedings involve the trial of a serious question of material consequence to the company", good faith considerations become relevant. ${ }^{60}$ This is so for the reason that a finding that the applicant possesses a collateral or ulterior purpose could also be of relevance in deciding whether or not the applicant acts in good faith. In the same vein, if proceedings are found not to be "in the best interests of the company", that could be a ground for finding absence of good faith on the part of the applicant.61 For this reason, these last-mentioned elements will receive brief attention below.

Section 165(5)(b) in particular, reads as follows:

"A person who has made a demand in terms of subsection (2) may apply to a court for leave to bring or continue proceedings in the name and on behalf of the company, and the court may grant leave only if -

...

(b) the court is satisfied that -

(i) the applicant is acting in good faith;

56 See the Act, sec $157(\mathrm{~b})$.

57 See id, sec 157(c), read together with sec 165(2)(c).

58 See id, sec $157(d)$.

59 Mbethe 2017, above at note 14, para 18.

60 Id, para 19.

61 Ibid. 
(ii) the proposed or continuing proceedings involve the trial of a serious question of material consequence to the company; and

(iii) it is in the best interests of the company that the applicant be granted leave to commence the proposed proceedings or continue the proceedings, as the case may be."

If a company that has been served with a demand in terms of section 165(2) fails to comply with the requirements of sub-sections 165(3) and (4) of the Act, this opens the door for a derivative action applicant to petition the court for leave to bring action on behalf of the company. ${ }^{62}$ An applicant has to establish the requirements set out in section 165(5) if the court is to exercise its discretion to grant leave in his/her favour. Before analysing key requirements such as the good faith criterion, for example, ${ }^{63}$ it is considered vital to deal with a preliminary issue. That issue pertains to the discretion to be exercised by the court.

\section{Whether the court's discretion is an overriding one or whether it is limited by section 165(5)}

It appears from the judgment by Swain JA in Mbethe 2017 that the SCA did not agree with the court a quo's obiter conclusion that the discretion to be exercised by the court is limited by the provisions of section 165(5). Quite clearly, the High Court's Wentzel AJ ${ }^{64}$ interpreted section 165(5) with respect to a court's discretion differently from the SCA's $s^{65}$ understanding of the same subsection. It is not difficult to understand why the two courts approached section 165(5) differently. The part in the introduction to section 165(5) that reads "the court may grant leave only" if certain requirements are met, potentially creates two meanings. The common denominator is that the sub-section permits discretion. The issue that may not be crystal clear from the wording of section 165(5) and has become debatable is whether this discretion permitted by the sub-section is an absolute discretion or a qualified discretion. While the SCA's Swain JA understood this to still result in an overriding discretion granted to courts as before, ${ }^{66}$ the High Court's Wentzel AJ did not even regard the sub-section to be granting discretion to courts. ${ }^{67}$ Wentzel AJ paid attention to the word "may", and I suspect also to the word "only", and understood the import of these words to be giving authority to the court to grant relief where the requirements set out in section 165(5) are satisfied. ${ }^{68}$

62 In terms of the Act, sec 165(5).

63 Other important requirements to be briefly examined include the requirement that it is in the best interests of the company to grant leave to bring derivative action and the requirement that the proposed proceedings involve trial of a serious question of material consequence to the company.

64 The Southern Gauteng Local Division of the High Court in Mbethe 2016, above at note 20.

65 Mbethe 2017, above at note 14, para 18.

66 See id, para 16.

67 Id, para 18.

68 Ibid. 
On closer scrutiny, the meaning of the phrase "court may grant leave only" should not be understood to be taking away the discretion from the court and imposing instead something akin to an obligation. It is argued that the court's exercise of discretion is retained under section 165(5). The import of the wording referred to above is to clarify the circumstances under which the court's discretion will be exercised. Thus, the requirements under section 165(5)(b) provide guidelines for the court's exercise of discretion. This serves the purpose of ensuring that the discretionary power of the courts is not exercised unreasonably. It can even be argued that this may ensure the avoidance of unfettered exercise of discretion. It could not have been the legislature's intention to grant courts unfettered discretion, lest this results in undesirable consequences.

It may be necessary at this stage to comment on the rationale or desirability of a court exercising discretion in granting leave to bring derivative action under section 165(5). In terms of the statutory action, the rationale for a court to exercise discretion is intricately linked to the law's imposition of an onus on an applicant to establish a prima facie case and cause of action against the wrongdoer, as recently confirmed by the court. ${ }^{69}$ This is necessary given that the essence of a derivative action is a departure from the norm, where a company, in its sole discretion, brings action for the wrongs done to itself. Now the company is compelled to do so against its free will, and the law must have a mechanism to ensure that there is no abuse of court process. The overriding discretion by the court provides what Cassim has beautifully termed a crucial "judicial filtering or screening mechanism". ${ }^{70}$ According to Swain JA, ${ }^{71}$ part of the rationale for the court's exercising of a discretion in terms of section 165(5) is the need to protect the administration of the business of the company against frivolous or vexatious claims, or claims which are not in the best interests of the company. Thus the judiciary fulfils a function akin to the role of "gatekeeper" in this regard.

Is the court's discretion an overriding one or is it limited by section 165(5)? Well, in light of the above, while the discretion that the court exercises with respect to section 165(5) should not be seen to be an unfettered discretion, neither can it be said to be limited by that sub-section. As demonstrated above, the exercise of the discretion crucially shields the company against vulnerability to abuse of process. It further serves the purpose of protecting the company against frivolous or vexatious claims. When the board, as a strategic management structure, fails to protect the legal interests of a company, the company is left rather like sheep without a shepherd. Thus the court has to play a guardianship role to safeguard company interests against potential abuse.

\footnotetext{
69 Id, para 15.

70 See Cassim "The statutory derivative action", above at note 32 at 501.

71 Mbethe 2017, above at note 14, para 15.
} 


\section{The good faith criterion - should SA still follow the Australian approach?}

In terms of section 165(5)(b)(i), it is implied that an applicant bears the onus to prove that the application to bring derivative action satisfies the requirement that he/she is "acting in good faith". ${ }^{72}$ Disputes often arise as to what needs to be precisely established to prove that the good faith requirement has been met. For this reason, the High Court in Mouritzen, through the Act's section 5(2) mechanism, imported into South African law the Australian good faith criterion developed in Swansson. ${ }^{73}$ The Swansson criterion, ${ }^{74}$ as adapted into South African law by Ndlovu J in Mouritzen, ${ }^{75}$ stands on two pillars. The first is whether the applicant honestly believes that a good cause exists and that there is a reasonable prospect of success. Whether the applicant honestly holds such a belief, according to Swansson, should not simply be a matter of bald assertion. ${ }^{76}$ The applicant may be disbelieved if no reasonable person in the circumstances could hold that belief. The second pillar is that the applicant must show that the application has not been brought for a collateral purpose, as that would amount to an abuse of process. ${ }^{77}$

The good faith criterion espoused in Swansson, and as adopted into South African law through Mouritzen, has a dual subjective/objective standard that is applicable. This dual subjective/objective dichotomy is possibly influenced by the standard of a director's statutory duty to "act in good faith and for a proper purpose". ${ }^{78}$ South Africa has now merged the two duties in statute, namely the duty to act in good faith and the duty to act for a proper purpose. These two duties are decoupled at common law - that is, they are separate but related. It is not clear whether South Africa was trying to follow the Australian example with regard to the manner in which it presents the two duties in section $76(3)(a) \cdot{ }^{79}$

The consequence of merging the two duties to result in one statutory duty to act in good faith and for a proper purpose is that the test is a dual subjective/objective one. Good faith largely depends, though not exclusively, on honesty. Honesty is subjective. ${ }^{80}$ A director's duty in this regard is to act in what he/she honestly and subjectively believes to be in the best interests of the

72 That sub-section provides that for a court to grant leave, it should be "satisfied that - (i) the applicant is acting in good faith". Thus it is the responsibility of the applicant to satisfy the court that he is acting in good faith.

73 See Mouritzen, above at note 22, para 58.

74 See Swansson, above at note 21, paras 36-37.

75 Mouritzen, above at note 22, para 58.

76 Swansson, above at note 21, paras 36-37.

77 Mouritzen, above at note 22, para 58.

78 See the Act, sec 76(3)(a).

79 Australia combines these two duties with respect to its business judgment rule elements. See sec 180(2)(a) of the Corporations Act 50 of 2001.

80 See a view expressed in F Cassim et al Contemporary Company Law (2012, Juta) at 524. 
company. ${ }^{81}$ Honesty is about an actor's subjective state of mind. ${ }^{82}$ Thus the good faith test is largely subjective, though the absence of reasonable grounds for the subjective belief may be grounds to find bad faith. ${ }^{83}$ Proper purpose, on the other hand, imposes an objective test. The purpose for which a power was given can be objectively determined. At common law, directors must exercise their powers for the objective purpose for which the power was given and not for a collateral purpose. ${ }^{84}$ This is how the "collateral purpose" considerations have become part of the good faith criterion in section 165(5)(b). It is borrowed from the dual subjective/objective dichotomy of the duty in section 76(3)(a), which itself borrows a lot from Australian statutory law. It is perhaps understandable, therefore, why it seemed natural to Ndlovu $\mathrm{J}^{85}$ to borrow a criterion developed by an Australian case, Swansson.

The dual nature of the good faith criterion as interpreted by courts ${ }^{86}$ has resulted in difference of opinion and, as is evident in the Mbethe 2017 judgment, will generate possible future disagreements within the legal fraternity. The SCA, in Mbethe 2017, was critical of the adoption of the good faith criterion in South African law as developed in the Australian Swansson case. ${ }^{87}$ Swain JA argues that the importation from Australian law of the good faith criterion is unjustified and impliedly incorrect. ${ }^{88}$ Swain JA is of the opinion that it was unnecessary to borrow from Australian law the reading into section 165(5) (b)(i) of the collateral or ulterior purpose element as a substantive self-standing requirement of good faith when it is comprehended in section 165(5)(b). Swain JA thus argues:

"It is therefore unnecessary to import this requirement as a self-standing requirement of the good faith inquiry, when it more appropriately arises in determining whether the question in issue is of material consequence to the company ... The court accordingly erred in concluding that an applicant in terms of s165(5) of the Act bore an onus of proving the absence of a collateral purpose, as a self-standing requirement of the good faith inquiry." 89

81 And not what the court may consider to be in the best interests of the company: Re Smith E Fawcett Ltd [1942] Ch 304 at 306.

82 Greenhalgh v Ardene Cinemas Ltd [1950] 2 All ER 1120 (CA).

83 See Shuttleworth $v$ Cox Brothers \& Co (Maidenhead Ltd) [1972] 2 KB 9 at 23; [1926] All ER Rep 498 (CA) 506.

84 See Howard Smith Ltd v Ampol Petroleum Ltd [1974] AC 821 (PC) where the board of a company used their powers to defeat a majority shareholding of a shareholder they did not like in preference to a shareholder they liked. The court found that the substantial purpose for which the board exercised its powers was not the proper purpose to serve the company's best interests, but to defeat the majority shareholding of Ampol Petroleum Limited in favour of a takeover bid from Howard Smith Limited.

85 In Mouritzen, above at note 22.

86 South African courts as demonstrated in the preceding paras.

87 See Mbethe 2017, above at note 14 at para 11.

88 Ibid.

89 Ibid. 
It is very clear from the comments of Swain JA that he disapproved of the importation into South African law of the Swansson good faith criterion through Mouritzen and as accepted in Mbethe $v$ United Manganese of Kalahari (Pty) Ltd 2016. ${ }^{90}$ If Swain JA is of the opinion that collateral purpose is comprehended in section 165(5), it is difficult to understand why there should be a problem in seeing it as part of the good faith criterion. After all, there is a very close link between absence of good faith and acting for a collateral purpose. The criterion as developed by Swansson demonstrates a clear overlap between lack of good faith and bringing derivative action for a collateral purpose. ${ }^{91}$ As was said in Swansson, where a court is not satisfied that the applicant actually holds the requisite belief, ${ }^{92}$ that fact alone would be sufficient to lead to the conclusion that the application must have been made for a collateral purpose. ${ }^{93}$ Interestingly, Swain JA in Mbethe 2017 arrived at a conclusion that the appellant failed to prove that "he acted in good faith" and that evidence "points inexorably to the presence of a collateral ulterior purpose on the part of the appellant". ${ }^{94}$ In addition, Swain JA found that the appellant "failed to discharge the onus of showing that he held the honest belief that the respondent possessed a good cause of action with reasonable prospects of success". ${ }^{95}$ It appears that Swain JA arrived at his conclusion using the same Swansson approach to establish the content of good faith as was adapted by Ndlovu J in Mouritzen (adapted from Swansson) when interpreting section 165(5)(b)(i).

It is also important to note that before Mouritzen, there was a gap in law as to what the content of the good faith requirement in section 165(5)(b)(i) should be. What the court in Mouritzen did was to consider a best practice jurisdiction whose approach to derivative actions was closer to our law (South African law). Ndlovu J in Mouritzen explored both Canadian, New Zealand and Australian laws to try and find guidance on espousing a relevant criterion for South Africa in terms of section 165(5)(b)(i). ${ }^{96}$ Ndlovu J, in my opinion, correctly found that section 237 of Australia's Corporations Act 2001 is closer to section 165 than the laws of New Zealand and Canada. Borrowing principles developed in a foreign jurisdiction is in any case permitted or even encouraged by the Act in section 5(2). This approach helps to promote the purposes of the Act, ${ }^{97}$ including the law reform goal of harmonization of South African

90 Above at note 20: the court a quo case whose decision was overturned by the SCA case presided over by Swain JA.

91 See Swansson, above at note 21, paras 36-37.

92 That is, the belief that a good cause of action exists and there is a reasonable prospect of success.

93 See Mouritzen, above at note 22, para 58.

94 Mbethe 2017, above at note 14, para 31.

95 Ibid.

96 Mouritzen, above at note 22 , para 36.

97 In this regard, the Act aims to continue to provide for the creation and use of companies, in a manner that enhances the economic welfare of South Africa as a partner within the global economy. See sec 7(e). 
law with the best practice jurisdictions internationally. ${ }^{98}$ For these reasons, I respectfully disagree with the judgment of Swain JA in Mbethe 2017 in as far as it relates to the content of the good faith criterion.

\title{
"The trial of a serious question of material consequence to the company" and acting "in the best interests of the company" requirements
}

The court in Mbethe 2017 somehow avoided espousing a criterion for the requirement that the proposed action involves "the trial of a serious question of material consequence to the company". ${ }^{99}$ While the court in Mouritzen did not apply itself to this requirement, the court in Mbethe 2017 resorted to demonstrating how failure to prove the other requirements under section 165(5)(b) will result in failure to prove that the proceedings involve a "trial of a serious question of material consequence to the company". This statement by Swain JA is telling in this regard:

\begin{abstract}
"In addition, if the evidence establishes the presence of a collateral or ulterior purpose on the part of the appellant, the pursuit of which does not involve the trial of a serious question of material consequence to the company, or which is not in the best interests of the company, this may also constitute cogent evidence of the absence of good faith on the part of the appellant."100
\end{abstract}

The court ${ }^{101}$ went on to refuse to grant leave to bring derivative action for reason of an appellant's failure to discharge the onus in terms of section 165(5)(b), including failure to prove the requirement that the proceedings involve the "trial of a serious question of material consequence to a company."102 The meaning of the phrase nonetheless remains elusive, and the court in Mbethe 2017 did not seize the opportunity to provide meaning to the phrase. In as much as the courts have attempted to establish the content of the good faith requirement, they must do the same for the phrase "trial of a serious question of material consequence to a company". The court in Mbethe 2017 literally side-stepped the issue and resorted to an interlinking of all the requirements an applicant should meet in terms of section 165(5)(b). Thus, the search for the true meaning of the phrase continues.

Traditionally, in other contexts, ${ }^{103}$ the requirement that a litigant proves that there is a "serious question to be tried" is applied in cases in which interim relief is sought. This seeks to require an applicant to prove that his claim is neither frivolous nor vexatious. ${ }^{104}$ In other words, the court must

\footnotetext{
98 See DTI Company Law for the 21st Century, above at note 30, para 3.5.

99 Which is a requirement that an applicant must prove in terms of sec 165(5)(b)(ii).

100 Mbethe 2017, above at note 14, para 22.

101 Ibid.

102 Id, para 31.

103 In constitutional matters, for example.

104 Ferreira v Levin; Vryenhoek v Powell 1995 (2) SA 813 (W).
} 
be satisfied that there is a serious matter to be tried. ${ }^{105}$ While this places a heavy burden on the applicant who approaches the court of law seeking relief, this also seeks to eliminate the abuse of court processes. In derivative action proceedings that take the form of motion proceedings, this typically involves a situation in which applications should be grounded on sufficient documentary evidence. This will give an indication to the court that there are prospects of success and that a claim will not amount to a frivolous and vexatious one.

A "trial of serious question of material consequence to a company" can be better understood if the phrase is broken down into two parts than otherwise. Let us start with the first part, the "trial of a serious question". In terms of case law, this phrase links this requirement to the content of the good faith criterion as established above through interpretation. A serious question to be tried by a court presupposes establishment of a good cause of action and also demonstration that there are reasonable prospects of success, ${ }^{106}$ which is part of the content of good faith. In terms of Australian law, the meaning attached to a similar phrase, "a serious question to be tried", ${ }^{107}$ is that the applicant should be able to specify the legal rights for determination by the court during trial. ${ }^{108}$ In other words, a litigant should be able to point out or indicate the legal right that it is claimed has been infringed and for which a remedy in the interest of the company is sought. ${ }^{109}$ The inquiry, one would suppose, turns on the merits of the case and reasonable prospects of success, based on questions of law to be proved, and the body of evidence gathered for this purpose.

The phrase "of material consequence to the company" should be interpreted to mean that if an applicant is to be allowed to litigate on behalf of the company, the matter must decidedly be in the interest of the company. This interlinks with the requirement that an applicant must prove that it is in the best interest of the company that leave to bring derivative action be granted by the court. ${ }^{110}$ What is of material consequence to the company is what should, after all has been said and done, advance the interests of the company as a whole.

In light of the above, it is becoming increasingly clear that there is a relationship between something of material consequence to the company and the best interests of that company. Thus, if it is to be accepted that the phrase "of material consequence to the company" includes consideration of what is in "the best interests of the company", then this potentially gives rise to another vexing question. What would the "best interests of the company"

105 American Cyanamid Co v Ethicon Ltd [1975] AC 396 [1975] 1 All ER 504 (HL).

106 Mouritzen, above at note 22, para 58. Also see Swansson, above at note 21, paras 36-37.

107 In terms of sec 237(2)(d) of the Corporations Act 50 of 2001.

108 See Goozee v Graphic World Group Holdings Pty Limited [2002] NSWSC 640.

109 For expression of a similar view, see F Cassim "The statutory derivative action under the Companies Act of 2008: Guidelines for the exercise of judicial discretion (2014 unpublished $\mathrm{PhD}$ thesis, University of Cape Town) at 66.

110 In terms of sec 165(5)(b)(ii) of the Act. 
encapsulate? A detailed examination of the phrase "the best interests of the company" in terms of section 76(3)(b) falls outside the scope of this article. It could briefly be stated here that the best interests of the company obviously include the legal interests of the company as a separate legal entity, its reputation, its stakeholders (including shareholders, employees, creditors etc), financial implications of court proceedings on the company, inter alia. In Mbethe 2017, the court interpreted section 165(5)(b)(iii) to include the fact that if there are alternative means of obtaining the same relief that do not involve the company being compelled to litigate against its wishes, this is an important consideration. ${ }^{111}$ In terms of Australian law, the court must be satisfied that the proposed derivative action is in fact in the best interests of the company, and not merely that it may be in the best interests of the company. ${ }^{112}$ It is not clear what Australian law exactly regards to be the meaning of "the best interests of the company". Mouritzen, which referred to Swansson in regard to the best interests of the company, found a natural connection between the best interests of the company and the good faith criterion. ${ }^{113}$ In this regard, Ndlovu $\mathrm{J}$ was persuaded that where an applicant is driven by an ulterior motive such as a personal vendetta against a member of the company, such an application cannot be said to be serving the best interests of the company. ${ }^{114}$ Indeed, it is true that an application whose substantial purpose is a self-serving ambition cannot be said to be of material consequence to the company, and thus invariably cannot be in the best interests of the company.

\section{CONCLUSION}

At the outset, this article proposed to answer three related research questions regarding what an applicant should prove in terms of section 165(5)(b) for the court to exercise its discretion to grant leave for derivative action. The first issue was to establish if courts still exercise an overriding discretion in granting leave for a derivative action or whether this discretion is now limited by section 165(5). The second question ${ }^{115}$ is whether South African courts should still follow the good faith criterion in the Australian case of Swansson imported into law through Mouritzen. Thirdly, this article set out to establish the content of the requirement that the proceedings involve "the trial of a serious question of material consequence to the company", ${ }^{116}$ which is related to the "best interests of a company"117 requirement, given that no court has yet

\footnotetext{
111 Mbethe 2017, above at note 14, para 33.

112 See Swansson, above at note 21, para 55.

113 Mouritzen, above at note 22, para 62.

114 Mouritzen, above at note 22, para 63.

115 Which is a consequence of the difference of opinion between the SCA and the court a quo in the recent case of Mbethe 2017, above at note 14 .

116 In terms of sec 165(5)(b)(ii) of the Act.

117 See id, sec 165(5)(iii).
} 
attempted to do so. ${ }^{118}$ Answering these questions, which are based on a statutory provision, namely section 165(5), naturally turned on matters of interpretation and an examination of the contribution of courts to the evolving principles.

With regard to the first inquiry, this article has demonstrated why the SCA's ruling in Mbethe 2017 that in terms of section 165(5) the courts retain an overriding discretion when granting leave for derivative action is sound and proper in law. For this reason, the court a quo's obiter conclusion that the courts' discretion is limited by section 165(5) was shown not to be properly aligned to policy rationales for the statutory derivative action and to be out of tune with the noble reasons why courts should exercise discretion in such matters. This article outlined the policy rationales for the statutory derivative action and demonstrated the purposes that the courts' exercise of discretion seeks to achieve. It has been argued that the court a quo perhaps misdirected itself by focusing on the words "may grant only" and wrongly concluded that this imposes an authority or obligation on the court to grant leave whenever the requirements set out in section 165(5)(b)(i)-(iii) have been met. The true import of the words when applied in conjunction with requirements set out in section 165(5)(b) is to clarify the circumstances under which the courts' discretion will be exercised.

On the inquiry whether South African courts should follow the Australian (Swansson approach to the) good faith criterion, this article has taken a different view to the SCA ruling in Mbethe 2017 in this regard. The SCA ruled that it was unnecessary to import the good faith criterion from Australia for the reason that it is comprehended in section 165(5)(b)(ii). Swain JA then went on to give a ruling which is clearly based on the very approach in Swansson. It has been argued that the court in Mouritzen espoused a good faith criterion based on a foreign case law approach, as permitted by section 5(2) of the Act, in order to close the gap that existed in law at the time. It has been demonstrated why the importation in Mouritzen of the Swansson approach is sound in law, and why the SCA's ruling in Mbethe 2017 does not, and perhaps should not, have the effect of altering the position in law as introduced by Mouritzen. It is hoped that the ruling in Mbethe 2017 will not create any uncertainty in the law regarding the correct approach. It is suggested that the comments of Swain JA should be treated as obiter only and should not have further effect in law.

This article ${ }^{119}$ established that a gap still exists in law regarding the clear content and criterion of the requirement that the proceedings should involve "the trial of a serious question of material consequence to the company". Even the SCA in Mbethe 2017 side-stepped the issue, yet the issue has been crying out for the courts' clarity for some time now. The positive thing to come out of the

118 That is to espouse the content of the requirement in ibid that the proceedings involve "the trial of a serious question of material consequence to the company".

119 With respect to the third inquiry. 
SCA's attempt is the manner in which Swain JA proposed to apply this requirement by interlinking it to other requirements in section 165(5)(b). This article points out that the over-elaborate phrase as adopted in section 165(5)(b)(ii) is not helpful in developing a clear criterion, nor in the courts' attempt to establish clear content of this requirement. Maybe that is the reason why courts have found it easier to adapt a criterion for good faith from Australia, but have struggled to establish a criterion for the section 165(5)(b)(ii) requirement. It is suggested, perhaps, that the clear phrase used in interim relief cases, and which has also been adopted in section 237(2)(d) of the Corporations Act 50 of 2001 in Australia, be used. The phrase used in the Australian act is a requirement that "there be a serious question to be tried". In future, when the opportunity to amend the Act arises, that clear formulation should be adopted in section 165(5)(b)(ii). Until that opportunity arises, however, courts should attempt to interpret the phrase in the manner proposed in this article, which would involve breaking down the requirement into smaller chunks.

\section{CONFLICTS OF INTEREST}

None 